\title{
PERANAN SEKTOR UNGGULAN TERHADAP PEREKONOMIAN DI KABUPATEN JAYAWIJAYA
}

\author{
Epra Wenda \\ O. Esry H. Laoh \\ Melissa L. G. Tarore
}

\begin{abstract}
This study aims to determine what sectors are the leading sectors and the role of superior sector to the economy within the last 5 years in Jayawijaya regency. This research is conducted for three months starting from June 2017 until August 2017 in Jayawijaya Regency. The data used in this study is secondary data obtained from the Central Bureau of Statistics (BPS) Jayawijaya district. The data is in though using descriptive analysis research method. The research shows that the sectors that are the leading sectors in Jayawijaya Regency are agriculture, forestry, fishery, processing industry sector, electricity, gas and water supply sector, construction sector, trade, hotel and restaurant sector, transportation and communications sector, and the services sector. The sectors of services, transport and communications, and the agricultural sector are the most contributing sectors in the economy compared to other leading sectors.
\end{abstract}

Keywords: role, leading sectors, economy, Jayawijaya district.

\begin{abstract}
ABSTRAK
Penelitian ini bertujuan untuk mengetahui sektor apa saja yang menjadi sektor unggulan dan bagaimana peranan sektor unggulan terhadap perekonomian dalam kurun waktu 5 tahun terakhir di kabupaten Jayawijaya. Penelitian ini dilakuakan selama tiga bulan mulai pada bulan Juni 2017 hingga Agustus 2017 di Kabupaten Jayawijaya. Data yang digunakan dalam penelitian ini adalah data sekunder yang di peroleh dari Badan Pusat Statistik (BPS) Kabupaten Jayawijaya. Data tersebut di olah menggunakan metode penelitian analisis deskriptif. Hasil penelitian menunjukkan sektor yang menjadi sektor unggulan di Kabupaten Jayawijaya adalah sektor pertanian, kehutanan, perikanan, sektor industri pengolahan, sektor listrik, gas, dan air bersih, sektor konstruksi, sektor perdagangan, hotel dan restoran, sektor pengangkutan dan komunikasi, sektor jasa keuangan, dan sektor jasa-jasa. Sektor Jasa-jasa, Pengangkutan dan komunikasi, dan sektor pertanian merupakan sektor yang menjadi paling banyak memberikan kontribusi dalam perekonomian dibandingkan dengan sektor unggulan lainnya.
\end{abstract}

Kata kunci: peranan, sektor unggulan, perekonomian, Kabupaten Jayawijaya.

\section{PENDAHULUAN}

\section{Latar Belakang}

Pembangunan di negara-negara berkembang pada umumnya termasuk di Indonesia masih memunculkan adanya dualisme yang mengakibatkan adanya kesenjangan antara daerah yang satu dengan daerah lainnya, antara kota dan desa, maupun antara dua kawasan pembangunan Indonesia yakni Kawasan Barat dengan Kawasan Timur Indonesia.

Pertumbuhan ekonomi merupakan masalah perekonomian dan merupakan fenomena penting yang dialami oleh perekonomian seluruh dunia, termasuk perekonomian Indonesia. Pertumbuhan ekonomi merupakan suatu tolak ukur adanya 
pembangunan ekonomi di suatu daerah. Pembangunan sektor ekonomi merupakan proses untuk mengubah suatu keadaan supaya lebih baik dengan tujuan untuk meningkatkan pendapatan, kesempatan kerja, dan kemakmuran masyarakat (Sukirno, 2006).

Masalah utama yang dihadapi oleh setiap negara yang berkembang termasuk Indonesia adalah pengangguran, ketimpangan distribusi pendapatan, dan kemiskinan. Perekonomian daerah sebagai pembentuk perekonomian nasional harus dikembangkan secara optimal sesuai dengan potensi yang dimiliki oleh daerah. Dengan adanya UU NO. 22 tahun 1999 mengenai otonomi daerah menuntut daerah untuk mengembangkan perekonomian berbasis sumber daya lokal. Dengan adanya otonomi, diharapkan pengembangan ekonomi daerah benar-benar berdasarkan aspirasi masyarakat. Salah satunya yaitu dengan pengembangan ekonomi lokal, yang pertumbuhannya diperlihatkan oleh Produk Domestik Regional Bruto (PDRB).

Keberhasilan pembangunan ekonomi daerah dapat dinilai dengan berbagai ukuran yang secara umum dapat diukur melalui besaran pendapatan nasional. Rincian pendapatan nasional berdasarkan sektor yang ada dapat menerangkan struktur perekonomian suatu daerah. Adapun sektor tersebut antara lain sektor pertanian, sektor pertambangan dan penggalian, sektor industri pengolahan, sektor listrik, gas dan air bersih, sektor konstruksi, sektor perdagangan, hotel dan restaurant, sektor pengangkutan dan komunikasi, sektor keuangan, persewaan dan jasa perusahaan, dan sektor jasa-jasa lainnya (BPS, 2015).

Untuk mencapai keberhasilan pembangunan ekonomi daerah, maka suatu daerah harus mengetahui sektor apa saja yang menjadi sektor unggulan didaerah tersebut. Demikian pula dengan Kabupaten Jayawijaya dalam mendorong pertumbuhan ekonominya maka perlu mengidentifikasi sektor-sektor mana yang dapat di unggulkan dan dapat memberikan hasil yang baik, sehingga diharapkan dapat menopang sektor-sektor lainnya yang belum berkembang.
Kabupaten Jayawijaya merupakan jantung dari Provinsi Papua dan merupakan salah satu wilayah di Provinsi Papua yang memiliki banyak kemajuan dalam segi perekonomian yang dicerminkan dalam angka pendapatan Domestik Regional Bruto (PDRB) dan pertumbuhan ekonomi dari tahun ke tahun. Kabupaten Jayawijaya berada pada posisi strategis dari beberapa kabupaten yang ada di bagian pegunungan tengah posisi strategis ini menjadikan Jayawijaya sebagai pintu gerbang dan memiliki potensi untuk menjadi pusat pertumbuhan ekonomi. Kabupaten Jayawijaya ini juga turut mendukung peran Pulau Papua sebagai pusat produksi dan pengolahan hasil pertanian, perkebunan, perikanan serta pertambangan.

Sejalan dengan perkembangan Indonesia dan sebagian besar wilayah Papua, perekonomian Kabupaten Jayawijaya selama tahun (2009-2013), total nilai tambah yang dihasilkan oleh aktifitas sektor-sektor ekonomi yang berada di wilayah Kabupaten Jayawijaya baik atas dasar harga berlaku maupun atas dasar harga konstan, secara konsisten mengalami peningkatan dari tahun ke tahun.

\section{Rumusan Masalah}

Berdasarkan latar belakang yang dikemukakan, maka yang menjadi rumusan masalah dalam penelitian ini adalah :

1. Sektor apakah yang menjadi unggulan di Kabupaten Jayawijaya.

2. Bagaimanakah peranan sektor unggulan terhadap perekonomian di Kabupaten Jayawijaya.

\section{Tujuan Penelitian}

Penelitian ini bertujuan untuk :

1. Mengetahui sektor unggulan di Kabupaten Jayawijaya.

2. Mengetahui peranan sektor unggulan terhadap perekonomian di Kabupaten Jayawijaya.

\section{Manfaat Penelitian}

Hasil dari penelitian ini diharapkan dapat memberikan manfaat bagi semua pihak, baik pemerintah daerah, penulis maupun peneliti selanjutnya. 
1. Bagi peneliti untuk menambah pengetahuan tentang peranan sektor unggulan dan pertumbuhan ekonomi, dan merupakan salah satu syarat untuk memperoleh gelar sarjana Fakultas Pertanian, Universitas Sam Ratulangi Manado.

2. Bagi peneliti selanjutnya, penelitian ini diharapkan dapat memberikan informasi dan refrensi tambahan dalam menggunakan studi yang relevan di masa yang akan datang.

3. Bagi pemerintah daerah Kabupaten Jayawijaya, diharapkan dapat dijadikan sebagai bahan pertimbangan dalam pengambilan keputusan dan perencanaan pembangunan daerah sehingga dapat mengoptimalkan perekonomian dengan memanfaatkan potensi ekonomi yang ada di daerah.

\section{METODOLOGI PENELITIAN}

\section{Lokasi dan Waktu Penelitian}

Penelitian ini dilaksanakan di Kabupaten Jayawijaya, Provinsi Papua. Penelitian ini dilakukan selama 3 (tiga) bulan, mulai dari bulan Juni sampai bulan Agustus 2017. Di mulai dari persiapan, pengambilan data, sampai penyusunan laporan hasil penelitian.

\section{Jenis dan Sumber Data Penelitian}

Jenis data yang digunakan dalam penelitian ini adalah data sekunder, yang bersumber dari Badan Pusat Statistik Kabupaten Jayawijaya dan Badan Pusat Statistik Provinsi Papua serta lembagalembaga pemerintahan, dan sumber-sumber lain seperti media cetak, jurnal-jurnal, dan literatur-literatur lain yang terkait dengan penelitian ini. Data yang tercakup dalam penelitian ini adalah data Produk Domestik Regional Bruto (PDRB) Tahun 2011-2015.

\section{Metode Penelitian}

Metode penelitian yang digunakan yaitu metode deskriptif yang digunakan untuk menganalisis data dengan cara mendeskripsikan atau menggambarkan data yang telah terkumpul.

\section{Konsepsi Pengukuran Variabel} adalah

Variabel yang diukur dalam penelitian ini

1. Produk Domestik Regional Bruto (PDRB) Kabupaten Jayawijaya ADHK Tahun 20112015.

2. Produk Domestik Regional Bruto (PDRB) Provinsi Papua ADHK Tahun 2011-2015.

\section{Metode Analisis Data}

Analisis yang digunakan dalam penelitian ini:

\section{Analisis Location Quotient (LQ)}

Metode ini membandingkan tentang besarnya peranan suatu sektor di suatu daerah terhadap besarnya peranan sektor tersebut di tingkat nasional atau di tingkat regional.

Teknik ini digunakan untuk mengidentifikasi potensi internal yang dimiliki daerah tersebut yaitu sektor basis dan merupakan sektor non basis (Kuncoro, 2004).

Keterangan:

$$
\mathrm{LQ}=\frac{S i}{S}: \frac{N i}{N}
$$

$$
\begin{array}{ll}
\mathrm{LQ} & =\text { Index Location Quotient } \\
\mathrm{Si} & =\text { PDRB sektor i di Kabupaten } \\
& \text { Jayawijaya } \\
\mathrm{S} & =\text { PDRB total Kabupaten Jayawijaya } \\
\mathrm{Ni} & =\text { PDRB sektor i di Provinsi Papua } \\
\mathrm{N} & =\text { PDRB total Provinsi Papua }
\end{array}
$$

Berdasarkan formulasi yang di tunjukkan dalam persamaan di atas, maka ada tiga kemungkinan nilai LQ yang diperoleh yaitu:

1) Nilai $L Q=1$. ini berarti bahwa tingkat spesialisasi sektor i di Kabupaten Jayawijaya adalah sama dengan sektor yang sama dalam perekonomian Provinsi Papua.

2) Nilai LQ > 1. ini berarti bahwa tingkat spesialisasi sektor i di Kabupaten Jayawijaya lebih besar dibandingkan dengan sektor yang sama dalam perekonomian Papua.

3) Nilai LQ < 1. Ini berarti bahwa tingkat spesialisasi sektor i di Kabupaten Jayawijaya lebih kecil dibandingkan sektor yang sama dalam perekonomian Provinsi Papua. 
Dengan kata lain apabila LQ > 1, maka dapat disimpulkan bahwa sektor tersebut merupakan sektor basis dan potensial untuk dikembangkan sebagai penggerak perekonomian Kabupaten Jayawijaya. Sebaliknya apabila nilai LQ < 1, maka sektor tersebut bukan merupakan sektor basis dan kurang potensial untuk dikembangkan sebagai penggerak perekonomian Kabupaten Jayawijaya.

\section{HASIL DAN PEMBAHASAN}

\section{Gambaran Umum Kabupaten Jayawijaya}

\section{Letak dan Kondisi Geografis}

Kabupaten Jayawijaya merupakan salah satu kabupaten di Provinsi Papua, Indonesia. Ibu Kota Kabupaten Jayawijaya terletak di Wamena (Lembah Baliem). Jayawijaya merupakan lembah di dataran tinggi dengan ketinggian rata-rata 1.550 meter diatas permukaan laut, terletak pada posisi 3.45'-4.2' Lintang Selatan, serta 138.3'-139.4' bujur Timur. Luas wilayah Kabupaten Jayawijaya, adalah berupa daratan seluas 13.925.31 km2. Kabupaten Jayawijaya merupakan Kabupaten induk dari seluruh Kabupaten yang berada di bagian pegunungan tengah antara lain Kabupaten Tolikara, Puncak Papua, pegunungan bintang, Yahukimo, Lanny Jaya, Mamberamo Tengah, Yalimo, dan Kabupaten Nduga. Adapun batasbatas wilayah Kabupaten Jayawijaya adalah sebagai berikut :

Sebelah Utara : Kabupaten MamberamoTengah, Kabupaten Yalimo, dan

Kabupaten Tolikara

Sebelah Selatan : Kabupaten Nduga dan Kabupaten Yahukimo

Sebelah Timur : Kabupaten Yalimo dan Kabupaten Yahukimo

Sebelah Barat : Kabupaten Lanny Jaya dan Kabupaten Nduga

\section{Keadaan Iklim}

Iklim di daerah Kabupaten Jayawijaya berada di hamparan Lembah Baliem. Terbentang pada areal ketinggian 1.500-2000 M di atas permukaan laut temperatur udara bervariasi antara $10.5^{\circ} \mathrm{C}$ sampai dengan $29.4^{\circ} \mathrm{C}$. Pada tahun 2016, suhu terendah ada pada bulan Agustus dengan rata-rata suhu udara $21.2^{\circ} \mathrm{C}$.

\section{Keadaan Penduduk}

Penduduk Kabupaten Jayawijaya berdasarkan proyeksi penduduk tahun 2015 sebanyak 206.320 jiwa yang terdiri atas 104.726 jiwa penduduk laki-laki dan 101.594 jiwa penduduk perempuan.

\section{Keadaan Perekonomian Kabupaten Jayawijaya}

Keadaan perekonomian Kabupaten Jayawijaya secara keseluruhan tercermin dari PDRB. Secara konsepsi, PDRB menggambarkan seberapa besar proses kegiatan ekonomi di suatu wilayah. Apa bila suatu sektor ekonomi mempunyai kontribusi kecil dan pertumbuhan melambat, maka hal tersebut akan menghambat laju pertumbuhan ekonomi secara keseluruhan.

Tingkat pertumbuhan secara keseluruhan merupakan rata-rata tertimbang dari tingkat pertumbuhan sektoralnya. Semakin besar peranan sektoral dalam struktur ekonomi, maka semakin besar pula kontribusinya terhadap tingkat pertumbuhan ekonomi.

\section{Analisis Data}

\begin{tabular}{|c|c|c|c|c|c|c|}
\hline \multirow{2}{*}{ Sektor } & \multicolumn{5}{|c|}{ Location Quotient (LQ) } & \multirow{2}{*}{ Ket } \\
\hline & 2011 & 2012 & 2013 & 2014 & 2015 & \\
\hline $\begin{array}{l}\text { Pertanian } \\
\end{array}$ & 1,50 & 1,41 & 1,41 & 1,37 & 1,35 & Unggulan \\
\hline Pertambangan & 0,03 & 0,03 & 0,03 & 0,03 & 0,03 & Non-Unggulan \\
\hline Industri Pengolahan & 1,22 & 1,16 & 1,21 & 1,12 & 1,13 & Unggulan \\
\hline Pengadaan Listrik dan Air Bersih & 1,73 & 1,66 & 1,67 & 1,57 & 1,55 & Unggulan \\
\hline Konstruksi & 1,47 & 1,41 & 1,42 & 1,38 & 1,37 & Unggulan \\
\hline Perdagangan Hotel dan Restoran & 2,11 & 1,90 & 1,90 & 1,84 & 1,86 & Unggulan \\
\hline Pengangkutan dan Komunikasi & 3,44 & 3,20 & 3,13 & 3,00 & 3,05 & Unggulan \\
\hline Jasa Keuangan & 1,11 & 1,05 & 1,09 & 1,03 & 1,04 & Unggulan \\
\hline Jasa-jasa & 1,69 & 1,56 & 1,58 & 1,44 & 1,42 & Unggulan \\
\hline
\end{tabular}

Tabel 1 analisis (LQ), menunjukkan bahwa dari seluruh sektor yang ada di Kabupaten Jayawijaya hanya sektor pertambangan dan penggalian yang menjadi sektor yang tidak unggul, dan sektor-sektor yang dapat diperdagangkan antar daerah di Kabupaten Jayawijaya dengan nilai (LQ>1) adalah sektor pertanian kehutanan dan perikanan, sektor industri pengolahan, Listrik Gas dan Air Bersih, Konstruksi, Perdagangan Hotel dan Restoran, Pengangkutan dan komunikasi, keuangan Real Estat dan Jasa Perusahaan, dan sektor Jasa-jasa. 


\section{Kontribusi Nilai Tambah Sektor Unggulan Terhadap PDRB Kabupaten Jayawijaya Periode 2011-2015}

Sektor unggulan mendominasi perekonomian di Kabupaten Jayawijaya dalam peranannya dibanding sektor-sektor lainnya. Peran sektor unggulan terhadap besarnya PDRB di Kabupaten Jayawijaya dapat di hitung dengan menggunakan rumus proporsi yaitu dengan cara membandingkan besarnya masingmasing nilai tambah dengan PDRB dikalikan $100 \%$.

\begin{tabular}{cccc}
$\begin{array}{c}\text { Tabel 2. Kontribusi Sektor Pertanian, Kehutanan, dan Perikanan Terhadap } \\
\text { PDRB Kabupaten Jayawijaya Tahum 2011-2015 }\end{array}$ \\
\hline Tahum & $\begin{array}{c}\text { PDRB Total } \\
\text { (Juta Rupiah) }\end{array}$ & $\begin{array}{c}\text { PDRB Sektor Pertanian, } \\
\text { Kehutanan dan Perikanan }\end{array}$ & $\begin{array}{c}\text { Kontribusi } \\
\mathbf{( \% )}\end{array}$ \\
\hline 2011 & $2.928,555,70$ & $502.826,10$ & 17,17 \\
2012 & $3.153,311,70$ & $531.685,20$ & 16,86 \\
2013 & $3.383,965,70$ & $559.799,00$ & 16,54 \\
2014 & $3.625,159,70$ & $594.103,80$ & 16,39 \\
2015 & $3.850,471,20$ & $614.860,90$ & 15,97 \\
\hline Rata-rata/Tahum & $\mathbf{3 . 3 8 8 , 2 9 2 , 8 0}$ & $\mathbf{5 6 0 . 6 5 5 , 0 0}$ & $\mathbf{1 6 , 5 9}$ \\
\hline
\end{tabular}

Tabel 2. kontribusi sektor unggulan terhadap Produk Domestik Regional Bruto (PDRB) Kabupaten Jayawijaya dari hasil analisis menunjukkan bahwa kontribusi sektor pertanian, kehutanan, dan perikanan memiliki nilai tertinggi berada pada tahun 2011 sebesar $17,17 \%$ dan nilai terrendah terdapat di tahun 2015 dengan nilai sebesar $15,97 \%$, dan secara rata-rata sebesar $16,59 \%$, per tahun selama periode 2011-2015.

\begin{tabular}{|c|c|c|c|}
\hline Tahum & $\begin{array}{l}\text { PDRB Total } \\
\text { (Juta Rupiah) }\end{array}$ & $\begin{array}{c}\text { PDRB Sektor } \\
\text { Industri Pengolahan }\end{array}$ & $\begin{array}{c}\text { Kontribusi } \\
(\%)\end{array}$ \\
\hline 2011 & $2.928,555,70$ & $74.481,30$ & 2,54 \\
\hline 2012 & $3.153,311,70$ & $76.823,00$ & 2,44 \\
\hline 2013 & $3.383,965,70$ & $80.840,80$ & 2,39 \\
\hline 2014 & $3.625,159,70$ & $83.980,70$ & 2,32 \\
\hline 2015 & $3.850,471,20$ & $86.044,00$ & 2,23 \\
\hline Rata-rata/Tahun & $3.388,292,80$ & $80.433,96$ & 2,38 \\
\hline
\end{tabular}

Tabel 3. Perhitungan melalui metode proporsi sektor unggulan terhadap PDRB Kabupaten Jayawijaya diperoleh hasil bahwa kontribusi dari sektor industri pengolahan terus mengalami penurunan yang signifikan, pada tahun 2011 sebesar $2,54 \%$ dan terus menurun pada tahun 2015 dengan kontribusi sebesar $2,23 \%$ dengan rata-rata terhadap PDRB Kabupaten Jayawijaya sebesar 2,38\% per tahun selama periode 2011-2015.
Tabel 4. Kontribusi Sektor Listrik, Gas dan Air Bersih Terhadap PDRB Kabupaten Jayawijaya Tahum 2011-2015

\begin{tabular}{cccc}
\hline Tahum & $\begin{array}{c}\text { PDRBTotal } \\
\text { (Juta Rupiah) }\end{array}$ & $\begin{array}{c}\text { PDRB Sektor Listrik, } \\
\text { Gas dan Air Bersih }\end{array}$ & $\begin{array}{c}\text { Kontribusi } \\
\mathbf{( \% )}\end{array}$ \\
\hline 2011 & $2.928,555,70$ & $4,339.90$ & 0,15 \\
2012 & $3.153,311,70$ & $4,709.20$ & 0,15 \\
2013 & $3.383,965,70$ & $5,018.70$ & 0,15 \\
2014 & $3.625,159,70$ & $5,178.40$ & 0,14 \\
2015 & $3.850,471,20$ & $5,065.90$ & 0,13 \\
\hline Rata-rata/Tahum & $\mathbf{3 . 3 8 8 , 2 9 2 , 8 0}$ & $\mathbf{4 , 8 6 2 . 4 2}$ & $\mathbf{0 . 1 4}$ \\
\hline \multicolumn{2}{l}{ Sumber : BPS Kabupaten Jayawijaya, 2016 (diolah) } \\
\end{tabular}

Tabel 4. Diatas dapat menunjukkan hasil bahwa kontribusi sektor Listrik, Gas dan Air Bersih terhadap PDRB Kabupaten Jayawijaya selama periode tahun 2011-2015 yaitu dengan rata-rata sebesar $0,14 \%$ selama periode 2011-2015. Dan kontribusi sektor listrik gas dan air bersih nilai paling rendah berada pada tahun 2015 dengan nilai sebesar $0,13 \%$.

Tabel 5. Kontribusi Sektor Konstruksi Terhadap PDRB Kabupaten Jayawijaya Tahun 2011-2015

\begin{tabular}{cccc}
\hline Tahum & $\begin{array}{c}\text { PDRB Total } \\
\text { (Juta Rupiah) }\end{array}$ & $\begin{array}{c}\text { PDRB Sektor } \\
\text { Konstruksi }\end{array}$ & $\begin{array}{c}\text { Kontribusi } \\
(\mathbf{\%})\end{array}$ \\
\hline 2011 & $2.928,555,70$ & $467,316.10$ & 15,96 \\
2012 & $3.153,311,70$ & $538,081.10$ & 17,06 \\
2013 & $3.383,965,70$ & $598,388.10$ & 17,68 \\
2014 & $3.625,159,70$ & $651,290.70$ & 17,97 \\
2015 & $3.850,471,20$ & $699,263.60$ & 18,16 \\
\hline Rata-rata/Tahum & $\mathbf{3 . 3 8 8 , 2 9 2 , 8 0}$ & $\mathbf{5 9 0 , 8 6 7 . 9 2}$ & $\mathbf{1 7 , 3 7}$ \\
\hline Sumber : BPS Kabupan
\end{tabular}

Sumber : BPS Kabupaten Jayawijaya, 2016 (diolah).

Tabel 6. Hasil perhitungan metode proporsi menunjukkan hasil bahwa kontribusi sektor konstruksi terhadap PDRB Kabupaten Jayawijaya terus mengalami peningkatan dari tahun ke tahun, pada tahun 2011 kontribusi sebesar $15,96 \%$ dan terus mengalami peningkatan pada tahun 2015 sebesar $18,16 \%$ dari tahun sebelumnya $17,97 \%$ pada tahun 2014.

\begin{tabular}{cccc}
$\begin{array}{c}\text { Tabel 6. Kontribusi } \\
\text { PDRB Kabtor Perdagangan, Hotel, dan Restoran Terhadap }\end{array}$ \\
\hline Tahum & $\begin{array}{c}\text { PDRB Total } \\
\text { (Juta Rupiah) }\end{array}$ & $\begin{array}{c}\text { PDRB Sektor Perdagangan, } \\
\text { Hotel dan Restoran }\end{array}$ & $\begin{array}{c}\text { Kontribusi } \\
\text { (\%) }\end{array}$ \\
\hline 2011 & $2.928,555,70$ & $473.694,70$ & 16,18 \\
2012 & $3.153,311,70$ & $496.439,10$ & 15,74 \\
2013 & $3.383,965,70$ & $538.474,00$ & 15,91 \\
2014 & $3.625,159,70$ & $579.034,40$ & 15,97 \\
2015 & $3.850,471,20$ & $623.149,00$ & 16,18 \\
\hline Rata-rata/Tahum & $\mathbf{3 . 3 8 8 , 2 9 2 , 8 0}$ & $\mathbf{5 4 2 . 1 5 8 , 2 4}$ & $\mathbf{1 6 , 0 0}$ \\
\hline
\end{tabular}

Sumber: BPS Kabupaten Jayawijaya, 2016 (diolah) 
Tabel 6. Menunjukkan hasil perhitungan melalui metode proporsi di peroleh hasil bahwa kontribusi sektor perdagangan, Hotel dan Restoran terhadap PDRB Kabupaten Jayawijaya mengalami peningkatan dan penurunan, sehingga pada tahun 2015 terjadi peningkatan sebesar $05,84 \%$ dari tahun sebelumnya $05,76 \%$ di tahun 2014 dengan ratarata kontribusi per tahun sebesar $05,77 \%$ selama periode tahun 2011-2015.

\begin{tabular}{cccc}
$\begin{array}{c}\text { Tabel 7. Kontribusi Sektor Pengangkutan dan Komunikasi Terhadap PDRB } \\
\text { Kabupaten Jayawijaya Tahum 2011-2015 }\end{array}$ \\
\hline Tahun & $\begin{array}{c}\text { PDRB Total } \\
\text { (Juta Rupiah) }\end{array}$ & $\begin{array}{c}\text { PDRB Sektor Pengangkutan } \\
\text { dan Komunikasi }\end{array}$ & $\begin{array}{c}\text { Kontribusi } \\
\mathbf{( \% )}\end{array}$ \\
\hline 2011 & $2.928,555,70$ & $694.242,00$ & 23,71 \\
2012 & $3.153,311,70$ & $748.164,60$ & 23,73 \\
2013 & $3.383,965,70$ & $797.406,20$ & $\mathbf{2 3 , 5 6}$ \\
2014 & $3.625,159,70$ & $857.122,40$ & 23,64 \\
2015 & $3.850,471,20$ & $919.611,40$ & 23,88 \\
\hline Rata-rata/tahum & $\mathbf{3 . 3 8 8 , 2 9 2 , 8 0}$ & $\mathbf{8 0 3 . 3 0 9 . 3 2}$ & $\mathbf{2 3 , 7 0}$ \\
\hline Sumber : BPS Kabupaten Jayawijaya, 2016 (diolah).
\end{tabular}

Tabel 7. Menunjukkan hasil perhitungan melalui metode proporsi bahwa kontribusi sektor Pengangkutan dan Komunikasi terhadap PDRB Kabupaten Jayawijaya selama tahun 2011-2015 terus terjadi peningkatan dari tahun 2011 sebesar $23,71 \%$ dan kontribusi pada tahun 2015 sebesar $23,88 \%$ dari tahun sebelumnya $23,64 \%$ pada 2014 dengan rata-rata per tahun sebesar $23.70 \%$ selama periode 2011-2015.

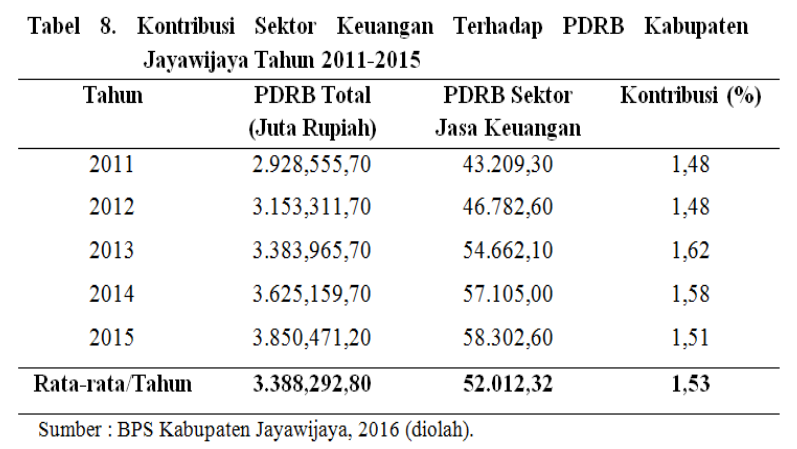

Pada Tabel 8. Menunjukkan hasil perhitungan melalui metode proporsi bahwa kontribusi sektor Keuangan, Real Estat dan Jasa Perusahaan terhadap PDRB Kabupaten Jayawijaya terus terjadi perubahan dari tahun ke tahun, pada tahun 2015 sebesar 1,51\% menurun dari tahun sebelumnya sebesar $1,58 \%$ pada tahun 2014 dengan rata-rata per tahun sebesar $1.53 \%$ selama periode $2011-2015$.
Tabel 9. Kontribusi Sektor Jasa-jasa Terhadap PDRB Kabupaten Jayawijaya Tahun 2011-2015

\begin{tabular}{cccc}
\hline Tahun & $\begin{array}{c}\text { PDRB Total } \\
\text { (Juta Rupiah) }\end{array}$ & $\begin{array}{c}\text { PDRB Sektor } \\
\text { Jasa-jasa }\end{array}$ & $\begin{array}{c}\text { Kontribusi } \\
(\mathbf{\%})\end{array}$ \\
\hline 2011 & $2.928,555,70$ & $623.141,60$ & 21,28 \\
2012 & $3.153,311,70$ & $661.710,50$ & 20,98 \\
2013 & $3.383,965,70$ & $697.065,30$ & 20,60 \\
2014 & $3.625,159,70$ & $742.464,80$ & 20,48 \\
2015 & $3.850,471,20$ & $787.738,60$ & 20,46 \\
\hline Rata-rata/Tahum & $\mathbf{3 . 3 8 8 , 2 9 2 , 8 0}$ & $\mathbf{7 0 2 . 4 2 4 , 1 6}$ & $\mathbf{2 0 , 7 6}$ \\
\hline Sumber:BPS Kabupaten Jayawijaya, 2016 (diolah) &
\end{tabular}

Sumber : BPS Kabupaten Jayawijaya, 2016 (diolah).

Pada Tabel 9. Menunjukkan hasil perhitungan melalui metode proporsi bahwa sektor Jasa-jasa merupakan salah satu sektor yang paling banyak memberikan kontribusi terhadap PDRB Kabupaten Jayawijaya dan terus terjadi peningkatan dan penurunan dari tahun ke tahun, kontribusi tertinggi berada pada tahun 2011 sebesar $21,28 \%$ dan di tahun 2015 memiliki nilai terrendah yakni sebesar $20,46 \%$, dengan rata-rata per tahun sebesar 23.81\%, selama periode 2011-2015.

\section{Pembahasan}

Sektor unggulan di Kabupaten Jayawijaya memiliki arti penting bagi perekonomian Kabupaten Jayawijaya. Hasil analisis data menunjukkan sektor-sektor yang menjadi sektor unggulan berdasarkan hasil perhitungan LQ tahun 2011-2015 di Kabupaten Jayawijaya terdapat delapan sektor unggulan.

Sektor unggulan di Kabupaten Jayawijaya selama tahun 2011-2015 adalah sektor Pertanian, Industri Pengolahan, Listrik, Gas dan Air Bersih, Konstruksi, Perdagangan, Hotel, dan Restoran, Pengangkutan dan Komunikasi, Keuangan, dan sektor Jasa-jasa.

Hasil analisis proporsi terhadap PDRB menunjukkan bahwa kontribusi sektor Unggulan di Kabupaten Jayawijaya selama tahun 2011-2015 yang mengalami kecenderungan menguat adalah sektor Jasa-jasa dengan nilai rata-rata sebesar $20,76 \%$, Sektor Pengangkutan dan Komunikasi dengan nilai rata-rata sebesar 23,70\%, Sektor Pertanian memiliki nilai rata-rata sebesar $16,59 \%$, Sektor perdagangan, hotel dan restoran sebesar $16,00 \%$ dan Sektor Konstruksi dengan nilai rata-rata sebesar $17,37 \%$. 


\section{KESIMPULAN DAN SARAN}

\section{Kesimpulan}

Berdasarkan hasil dan pembahasan diatas, maka sektor unggulan di Kabupaten Jayawijaya adalah Sektor Pertanian, Sektor Industri Pengolahan, sektor Listrik, Gas dan Air Bersih, Sektor Konstruksi, sektor Perdagangan, Hotel, Restoran, dan sektor Pengangkutan dan Komunikasi, Sektor Keuangan serta Sektor Jasa-jasa.

Sektor unggulan yang berperanan penting dalam perekonomian di Kabupaten Jayawijaya adalah sektor Jasa-jasa, sektor pengangkutan dan komunikasi, sektor pertanian, perdagangan, hotel dan restoran, dan sektor konstruksi.

\section{Saran \\ Pemerintah daerah Kabupaten} Jayawijaya berupaya dalam menjaga kinerja sektor uggulan yang meliputi sektor Pertanian, sektor Industri Pengolahan, Sektor Listrik Gas dan Air Bersih, sektor Konstruksi, sektor Perdagangan Hotel dan Restoran, sektor Pengangkutan dan Komunikasi, sektor Keuangan, dan Sektor Jasa-jasa, sehingga terus tumbuh dan berkembang dalam memenuhi kebutuhan daerah sendiri maupun mengekspor ke daerah lain sehingga menjadi peranan penting terhadap perekonomian di Kabupaten Jayawijaya.

\section{DAFTAR PUSTAKA}

Anonimous. Badan Pusat Statistik. Provinsi Papua. 2016. Produk Domestik Regional Bruto Menurut Lapangan Usaha 20112015. Jayapura.

Anonimous. Badan Pusat Statistik. Kabupaten Jayawijaya. 2016. Produk Domestik Regional Bruto. Menurut Lapangan Usaha 2011-2015. Wamena.

Anonimous. Badan Pusat Statistik Kabupaten Jayawijaya.2016. Jayawijaya Dalam Angka 2015. Wamena.

Anonimous. Badan Pusat Statistik Kabupaten Jayawijaya. 2017. Jayawijaya Dalam Angka 2016. Wamena.
Adisasmita, Rahardjo. 2008. Pengembangan Wilayah, Konsep Dan Teori. Graha Ilmu. Yogyakarta.

Arsyad, Lincolin. 2010. Ekonomi Pembangunan. STIE YKPN. Yogyakarta

Ambardi, U. M dan Socia, P. 2002. Pengembangan Wilayah dan Otonomi Daerah. Pusat Pengkajian Pengembangan Wilayah. Jakarta.

Bagus. 2011. Peranan Sektor Pertanian Dalam Perekonomian Di Kabupaten

Wonogiri. Skripsi. Fakultas Pertanian Universitas Sebelas Maret. Surakarta.

Basuki dan Gayatri. 2009. Penentuan Sektor Unggulan Dalam Pembangunan Daerah. Studi Kasus Di Kabupaten Ogan Komering Ilir.

Fachrurazy. 2009. Analisis Penentuan Sektor Unggulan Perekonomian Wilayah Kabupaten Aceh Utara. Lhosukon.

Gravitiani E. 2006. Analisis Shift-Share Dinamika Pada Perekonomian. Yogyakarta. Skripsi. FE.UGM. Yogyakarta.

Ghufron, Muhammad. 2008. "Analisis Pembangunan Wilayah Berbasis Sektor Unggulan Kabupaten Lamongan Provinsi Jawa Timur".Skripsi, Institut Pertanian Bogor.

Hasbiullah S. 2015. Analisis Penentuan Sektor Unggulan Perekonomian Kabupaten Bulukumba. Skripsi. Fakultas Ekonomi dan Bisnis Islam UIN Alauddin Makkassar. Bulukumba.

Indriyaty F. 2011. Peranan Sektor Basis Terhadap Penyerapan Tenaga Kerja Di Kabupaten Gresik. Skripsi. Fakultas Ekonomi. Unesa. Surabaya.

Jhingan, 2000. Ekonomi Pembangunan dan Perencanaan. Rajawali. Jakarta.

Ponto M. Dkk. 2010. Analisis Penentuan Sektor Unggulan Perekonomian Terhadap Penyerapan Tenaga Kerja Di Kota Jayapura. Fakultas Ekonomi Dan Bisnis, Jurusan Ilmu Ekonomi Pembangunan, Skripsi.Universitas Sam Ratulangi. Manado. 
Putri R. 2010. Peranan Sektor Basis Terhadap Pertumbuhan Ekonomi Provinsi Sumatera Barat. Skripsi. Fakultas Ekonomi Universitas Andalas. Padang.

Rompas J Dkk. 2015. Potensi Sektor Pertanian Dan Pengaruhnya Terhadap Penyerapan Tenaga Kerja Di Kabupaten Minahasa Selatan. Jurnal Berkala Ilmiah. Fakultas Ekonomi dan Bisnis. Unsrat. Manado.

Savitri D. 2008. Analisis Identifikasi Sektor Unggulan Dan Struktur Ekonomi Pulau Sumatera. Skripsi. Fakultas Ekonomi Dan Manajemen Institut Pertanian Bogor.

Setiawan M. 2014. Analisis Sektor Ekonomi Basis Dalam Mendorong Pertumbuhan Ekonomi Kota Batu. Jurnal Ilmiah. Fakultas Ekonomi dan Bisnis. Universitas Brawijaya. Malang.

Setiawan. 2006. Peranan Sektor Unggulan Terhadap Pertumbuhan Ekonomi Daerah Pendekatan Input-Output Multi Regional Jawa Timur, Bali, dan Nusa Tenggara Barat. Skripsi. Institut Pertanian Bogor.

Suryana, 2000. Teori-teori Pertumbuhan Ekonomi, Ekonomi Pembangunan: Teori, Masalah dan Kebijakan. UPP AMP YKPN. Yogyakarta.

Sukirno.2006. Ekonomi Pembangunan, Edisi Kedua Proses, Masalah, dan Dasar Kebijakan, Prenadamedia group Jakarta.

Tambunan, Tulus. 2001. Perekonomian Indonesia. Ghalia Indonesia, Jakarta.

Tarigan, Robinson. 2005. Ekonomi Regional: Teori dan Aplikasi. Edisi Revisi. Bumi Aksara. Jakarta.

Tambunan, T. H Tulus. 2003. Perekonomian Indonesia Beberapa Masalah Penting. Ghalia Indonesia. Jakarta.

Todaro, Michael P. 2000. Pembangungan Ekonomi Di Dunia Ketiga. Edisi Ketujuh. Jilid I. Terjemahan. Penerbit Erlangga. Jakarta. 